\title{
ISOLATION OF AN ACIDIC GLYCOPROTEIN FROM RABBIT OVIDUCAL FLUID AND ITS ASSOCIATION WITH THE EGG COATING
}

\author{
STANLEY S. SHAPIRO, NORMAN E. BROWN AND ALLAN S. YARD \\ Hoffmann-La Roche Inc., Nutley, Newe Jersey 07110, U.S.A.
}

(Received 19th September 1973)

\begin{abstract}
Summary. A high molecular weight acidic glycoprotein has been isolated from rabbit oviducal fluid. Electrophoretic analysis of this purified glycoprotein showed one major component. Antibodies to the glycoprotein were raised in the goat, concentrated by ammonium sulphate precipitation and conjugated with fluorescein isothiocyanate. The conjugated antibodies reacted with 3-day-old rabbit eggs causing them to fluoresce green in u.v. light, but 4-day-old eggs, which have largely lost their coat, did not react significantly with the antibody. These observations suggest that the high molecular weight acidic glycoprotein in oviducal fluid participates in the egg-coating process.
\end{abstract}

\section{INTRODUCTION}

In order to understand the functions of the mammalian oviduct, it is necessary to identify the components of oviducal fluid. Hamner \& Williams (1965) have reported the total protein, carbohydrate and electrolyte composition of rabbit oviducal fluid. The protein composition was further detailed by Shapiro, Jentsch \& Yard (1971), who concluded that proteins in oviducal fluid resulted from secretion as well as transudation from plasma.

In many species (Bacsich \& Hamilton, 1954), and particularly in the rabbit, a 'mucin' coat is deposited around the ovum during passage along the oviduct to the uterus. Braden (1952) concluded this material to be acidic mucoprotein after subjecting it to various dyes, proteases, hydrogen ion concentrations and oxidizing and reducing agents.

Hamner \& Fox (1969) reported that the rabbit oviduct is rich in secretory granules that are periodic acid-Schiff (PAS) positive and diastase resistant.

We have investigated the nature of the 'mucin'-like material in oviducal fluid as part of a continuing study on the protein composition of rabbit oviducal fluid. We now report on the isolation of an acidic glycoprotein from oviducal fluid which we believe to be involved in coating of the egg.

\section{MATERIALS AND METHODS}

Collection of oviducal fluid

Oviducal fluid was collected by the method of Hamner \& Williams (1965) and contained 1.5 to $2.5 \mathrm{mg}$ protein $/ \mathrm{ml}$. 
Purification of acidic glycoprotein

Pooled oviducal fluid $(100 \mathrm{ml})$ was freeze-dried, redissolved in $2.5 \mathrm{ml}$

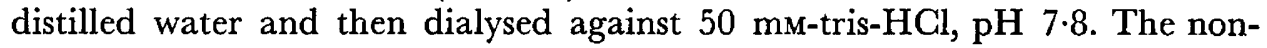
dialysable fraction was applied to a $50 \times 2.5 \mathrm{~cm}$ Sepharose $4 \mathrm{~B}$ column and eluted with 50 mm-tris-HCl, $\mathrm{pH} 7 \cdot 8$ (Text-fig. 1a). The void volume peak (Text-fig. 1a, I, shaded area) was fractionated again on the same column. The tubes from the second fractionation that contained Alcian blue (acidic carbohydrate) and Ponceau S (protein)-staining material were combined (Text-fig. 1b, shaded area) and referred to as the acidic glycoprotein.

\section{Immunization to oviducal fuid acidic glycoprotein}

The acidic glycoprotein isolated by Sepharose gel fractionation was concentrated to $2 \mathrm{mg}$ protein/ml (Sepharose $4 \mathrm{~B}$ has an exclusion limit of $3 \times 10^{6}$ daltons). A 2-ml volume of the glycoprotein was mixed thoroughly with an equal volume of Freund's adjuvant (Baltimore Biological Laboratories) containing Mycobacterium butyricum and 1.0-ml portions of the mixture were injected intramuscularly into each thigh of a male goat. After 10 weeks, a 2-ml booster dose of similarly treated antigen was injected subcutaneously and, 3 weeks later, the goat was bled from the jugular vein and antibodies to oviducal fluid were detected by the technique of Ouchterlony (1953).

\section{Preparation of fluorescent goat anti-rabbit oviducal acidic glycoprotein}

Goat serum was brought to $50 \%$ saturation with respect to $\left(\mathrm{NH}_{4}\right)_{2} \mathrm{SO}_{4}$ by slowly adding an equal volume of saturated $\left(\mathrm{NH}_{4}\right)_{2} \mathrm{SO}_{4}$ at $0^{\circ} \mathrm{C}$. The precipitate was centrifuged and redissolved in distilled $\mathrm{H}_{2} \mathrm{O}$ to give a final volume equal to the original serum. An equal volume of saturated $\left(\mathrm{NH}_{4}\right)_{2} \mathrm{SO}_{4}$ was again added. The precipitated globular fraction was centrifuged, redissolved in saline, and dialysed against saline overnight at $4^{\circ} \mathrm{C}$.

Labelling of the globular proteins with fluorescein isothiocyanate (FITG) was carried out according to the method of Clark \& Shepard (1963). The removal of excess dye from the fluorescein conjugate was accomplished with a Sephadex G-25 column $(0.5 \times 13 \mathrm{~cm})$. The degree of conjugation was $4.5 \mathrm{~mol}$ FITC/mol protein as determined by the absorbance of the protein at $493 \mathrm{~nm}$ and $276 \mathrm{~nm}$ according to the method of Wells, Miller \& Nadel (1966). There was no apparent physicochemical change in the FITC-conjugated antiglycoprotein compared to unconjugated antiglycoprotein as judged by immunoelectrophoresis and double diffusion studies.

\section{Double diffusion studies}

Double diffusion studies were performed at room temperature for 48 to $72 \mathrm{hr}$ in agarose gels (Kallestad Labs). A sample of $30 \mu$ l antiserum containing $100 \mathrm{mg}$ protein $/ \mathrm{ml}$ was applied to the centre well. The antigen well contained $30 \mu \mathrm{l}$ glycoprotein at a concentration of $2 \mathrm{mg}$ protein $/ \mathrm{ml}$.

\section{Cellulose acetate electrophoresis}

Electrophoresis was performed on cellulose acetate (Gelman) strips in 0.05 M-sodium barbital buffer, $\mathrm{pH} 8 \cdot 6$, for $120 \mathrm{~min}$ at $1.5 \mathrm{~mA} / \mathrm{strip}$. 
Incubation of fuorescent antibody with egg

The FITC-labelled antibody $(0.1 \mathrm{ml}$ containing $100 \mathrm{mg}$ of protein $/ \mathrm{ml})$ was incubated with $0.9 \mathrm{ml}$ saline containing two 3-day-old rabbit eggs for $4 \mathrm{hr}$. After incubation, the eggs were washed twice in $1 \cdot 5-\mathrm{ml}$ portions of saline for $1 \mathrm{hr}$ each and allowed to stand overnight in a fresh $1.5 \mathrm{ml}$ aliquot of saline. The last wash was clear. When the eggs were examined microscopically with a u.v. light source, they fluoresced green indicating common antigenic determinants on both the isolated glycoprotein and the 3-day-old eggs taken from a rabbit mated with a fertile buck.

\section{Lysis of 3-day-old eggs}

Forty-three 3-day-old eggs were lysed in $0.1 \mathrm{ml}$ solution of $2 \%$ sodium lauryl sulphate (SLS) and 2\% mercaptoethanol in water. After lysis, the SLS and mercaptoethanol were removed by exhaustive dialyses against $0.05 \mathrm{M}$-tris, $\mathrm{pH} 8.6$, containing $0.25 \%$ bovine serum albumin over 4 days with frequent changes of buffer. The resulting dialysate was concentrated to $30 \mu \mathrm{l}$ by ultrafiltration (Schleicher \& Schuell, Inc.) at room temperature. This concentrated lysate was used for reaction against anti-acidic glycoprotein.

\section{Amino acid analysis}

Samples of the glycoprotein were dialysed exhaustively against distilled water and then evaporated to dryness. The dried material was dissolved in $3.0 \mathrm{ml}$ of $6.0 \mathrm{~N}-\mathrm{HCl}$ and hydrolysed in vacuo for $24 \mathrm{hr}$ at $100^{\circ} \mathrm{C}$. The hydrolysate was evaporated to dryness, dissolved in $3.0 \mathrm{ml}$ distilled water, and again taken to dryness. This operation was performed three times before finally drying the sample in vacuo over $\mathrm{NaOH}$. The dried sample was dissolved in $0.6 \mathrm{ml}$ of 0.01 $\mathrm{N}-\mathrm{HCl}$ and an aliquot of $0.5 \mathrm{ml}$ was applied to a Technicon amino acid analyser.

\section{Neutral and amino sugars}

The neutral and amino sugars were analysed by a procedure modified from Albersheim, Nevins, English \& Karr (1967). The glycoprotein was hydrolysed in $2 \mathrm{~N}-\mathrm{HCl}$ for $3 \mathrm{hr}$ at $100^{\circ} \mathrm{C}$. The $\mathrm{HCl}$ was removed in vacuo over $\mathrm{NaOH}$ pellets. The sample was dissolved in $0.005 \mathrm{M}-\mathrm{NH}_{4} \mathrm{OH}, 10 \mathrm{mg} \mathrm{NaBH}_{4}$ was added and the mixture was allowed to stand for 18 to $20 \mathrm{hr}$ at room temperature. This solution was brought to $\mathrm{pH} 5$ with glacial acetic acid and applied to a Dowex-50 $\left(\mathrm{H}^{+}\right)$column to remove the sodium. The column was washed with 10 bed volumes of distilled water and these washings were taken to dryness. The dried residue was washed with methanol to remove borate (as the trimethylester). Pyridine $(30 \mu \mathrm{l})$ and acetic anhydride $(30 \mu \mathrm{l})$ were added to the dried material and heated to $100^{\circ} \mathrm{C}$ for $20 \mathrm{~min}$ to form the sugar acetates. The reactants were removed under reduced pressure.

The dry sample was dissolved in 20 to $50 \mu \mathrm{I} \mathrm{CHCl}_{3}$ and then analysed on a Hewlett-Packard model 402 gas chromatograph equipped with a flame ionization detector and a model 3378 digital integrator. The column was packed with Gas-Chrom Q, 100 to 120 mesh, precoated with a mixture of $0.2 \%$ stabilized ethylene glycol succinate, $0.2 \%$ stabilized ethylene glycol 
adipate, and $0.4 \%$ silicone XF-1150. The packing was obtained from Applied Science Labs.

The acetates of the following sugars were prepared and used as standards: 2-deoxyribose, rhamnose, fucose, ribose, arabinose, xylose, mannose, galactose, glucose, inositol and 2-deoxyhexose. The detector gave a linear response to all the standards. The variation in response to each sugar was determined. Samples were usually injected three times and the values for the areas under the peaks were averaged.

\section{Sialic acid}

Free sialic acid was determined by the thiobarbituric acid method of Warren as described by Spiro (1966). Free sialic acid was generated by hydrolysis of the glycoprotein with $0.5 \mathrm{~N}-\mathrm{H}_{2} \mathrm{SO}_{4}$ at $80^{\circ} \mathrm{C}$ for $1 \mathrm{hr}$ or by incubation overnight with neuraminidase in $0.01 \mathrm{M}$-acetate buffer, $\mathrm{pH} 5 \cdot 8$. The sample was dialysed against 50 mM-tris- $\mathrm{HCl}, \mathrm{pH} 7 \cdot 8$. The dialysate was concentrated before assaying for sialic acid.

Uronic acids were determined by the carbazole method of Dische (1947).

\section{Sulphate determination}

Covalent sulphate was determined by the method of Antonopoulos (1962).

\section{Protein determination}

Protein concentrations were determined by the method of Lowry, Rosebrough, Farr \& Randall (1951).

\section{Molecular weight determination}

The molecular weight of the acidic glycoprotein subunit was determined by the method of Shapiro, Viñuela \& Maizel (1967). Ovalbumin, catalase and phosphorylase (Worthington), and $\gamma$-globulin (Miles) were used as standards.

\section{RESULTS}

\section{Purification of acidic glycoprotein}

The fractionation of oviducal fluid on Sepharose 4B column resulted in four major protein peaks (Text-fig. 1a). Acidic glycoprotein(s) were detectable only in the excluded fraction (I), which stained with both Alcian blue and Ponceau S. Fractions II, III and IV were stained by Ponceau S but not Alcian blue. The void volume (Peak I) was opaque and appeared to represent a major constituent of the fluid, but it contained only 2 to $3 \%$ of the oviducal fluid protein. This void volume peak was fractionated a second time on a Sepharose 4B column and eluted as a single peak with a small but consistent amount of tailing (Text-fig. 1b). Disc gel electrophoresis was not possible due to the large molecular weight of glycoprotein.

After purification, the acidic glycoprotein had a tendency to precipitate and exist as a viscous gelatinous material. This transformation was accelerated by freezing and thawing.

Electrophoresis of the eluate from the Sepharose $4 \mathrm{~B}$ column was performed 


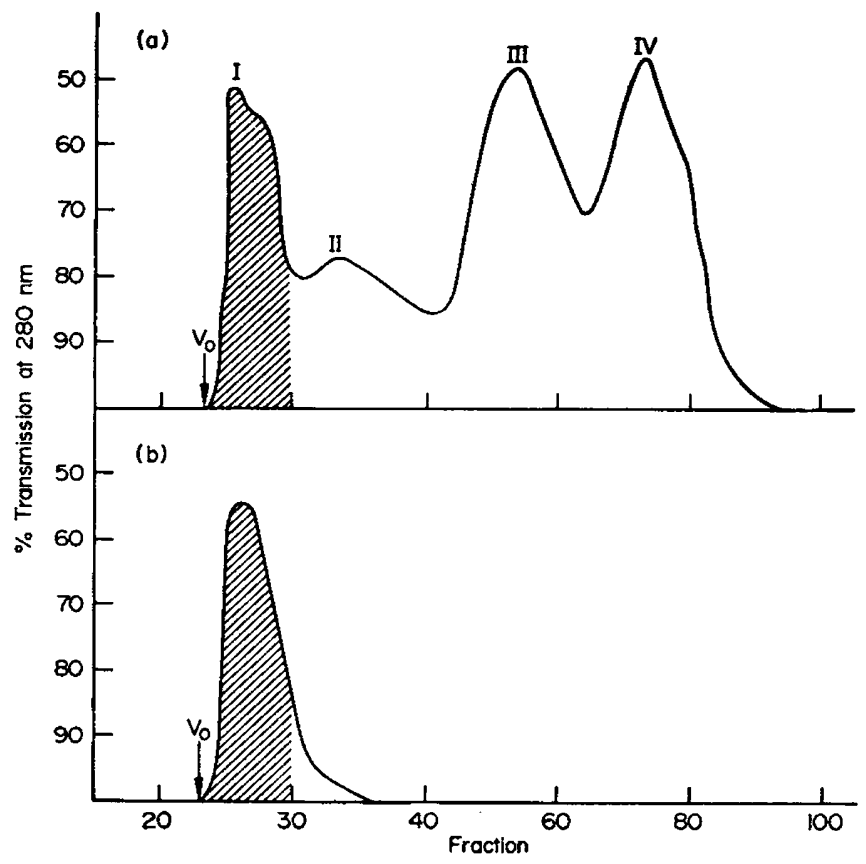

TeXT-FIG. 1. The Sepharose 4B fractionation of pooled rabbit oviducal fluid. Column conditions are described under 'Materials and Methods'. (a) Fractionation of rabbit oviducal fluid, flow rate $=12 \mathrm{ml} / \mathrm{hr}, 4 \mathrm{ml} /$ tube collected. The shaded area (void volume) was pooled, concentrated and fractionated. (b) Refractionation of void volume peak from ' $a$ '. The conditions were similar to those described for ' $a$ '. The shaded area represents pooled tubes. $\mathrm{V}_{0}=$ void volume.

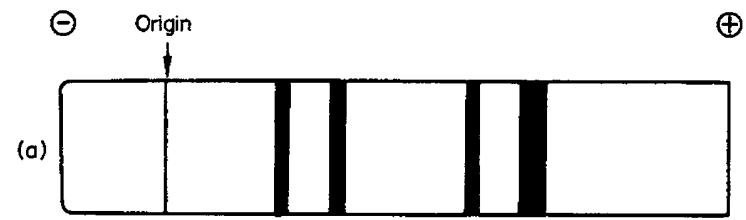

(b)

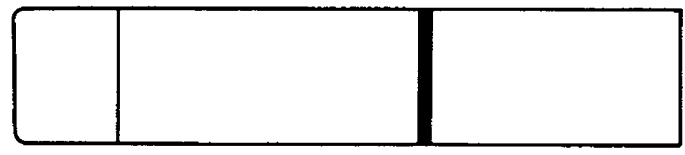

(c)

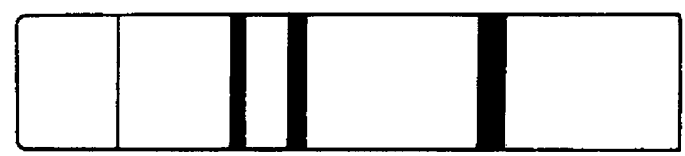

Text-Fig. 2. Cellulose acetate electrophoresis of acidic glycoprotein. The conditions of electrophoresis are described under 'Materials and Methods'. (a) Oviduct fluid, stained with Ponceau S; (b) Peak I, stained with Ponceau S or Alcian blue; (c) Peaks II, III and IV, stained with Ponceau S. 
on cellulose acetate strips in sodium barbital buffer at $\mathrm{pH} 8.6$. Peak I was compared with the combined Peaks II, III and IV. The strips were stained for protein with Ponceau $S$ and for glycosoaminoglycans with Alcian blue. Peak I from the Sepharose 4B column showed only one protein band which also stained with Alcian blue (Text-fig. 2b). Pooled Peaks II, III and IV from the Sepharose 4B column showed three major Ponceau S-positive bands and no Alcian blue-positive bands. None of the three protein bands of pooled Peaks II, III and IV corresponded to the protein band in Peak I (Text-fig. 2c).

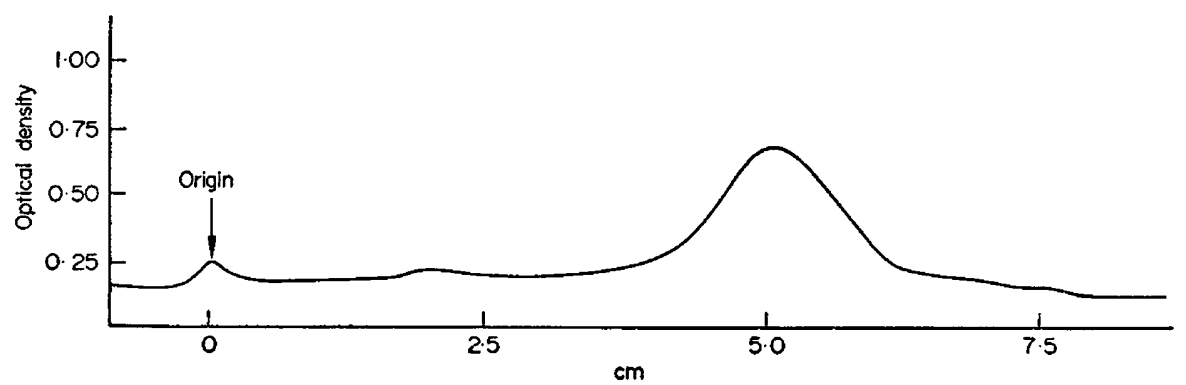

TEXT-FIG. 3. Densitometric tracing of acidic glycoprotein subjected to electrophoresis on cellulose acetate strips. The conditions of electrophoresis are described under 'Materials and Methods'. The tracing was obtained with a photovolt densitometer after staining the strips with Ponceau S.

When the glycoprotein sample was subjected to electrophoresis in barbitalacetate buffer at $\mathrm{pH} \mathrm{8.6}$ and stained for either protein (Ponceau S) or carbohydrate (PAS or Alcian blue), only one major band was observed with a densitometer (Text-fig. 3), but there was usually some glycoprotein material at the origin. The relative ratio of the mobile band to the origin band varied from preparation to preparation and with the age of the sample. For some preparations, the major portion of the material subjected to electrophoresis remained at the origin. The mobile band was always converted to the immobile insoluble band by repeated freezing and thawing or by ageing.

Freshly prepared acidic glycoprotein in combination with antibody gave a single precipitant band (Pl. 1, Fig. 1). As the sample became more gelatinous after ageing or freezing and thawing, multiple bands appeared in the Ouchterlony plate and remained very close to the antigen well.

\section{EXPLANATION OF PLATE 1}

FIG. 1. Double-diffusion study of glycoprotein and anti-glycoprotein. The conditions for the double-diffusion studies are described under 'Materials and Methods'. The centre well (A) contained $30 \mu \mathrm{l}$ immunized goat serum containing $100 \mathrm{mg}$ protein $/ \mathrm{ml}$. Antigen wells $(G)$ contained $30 \mu 1$ glycoprotein containing approximately $2 \mathrm{mg}$ protein $/ \mathrm{ml}$.

Fig. 2. Disc gel electrophoresis of sodium lauryl sulphate-treated glycoprotein. The conditions for dissociation and electrophoresis are described under 'Materials and Methods' (50 $\mu$ g protein was subjected to electrophoresis).

Frg. 3. Reaction of lysed eggs with anti-glycoprotein. The conditions for lysis are described under 'Materials and Methods'. The centre well contained $30 \mu \mathrm{l}$ immunized goat serum containing $100 \mathrm{mg}$ protein $/ \mathrm{ml}$. Well $\mathrm{E}$ contained the lysate from seventeen 3-day-old eggs in $30 \mu \mathrm{l}$. Well $\mathrm{G}$ contained $30 \mu \mathrm{l}$ glycoprotein containing $\mathrm{l} \mathrm{mg}$ protein/ml. 
PIATE 1

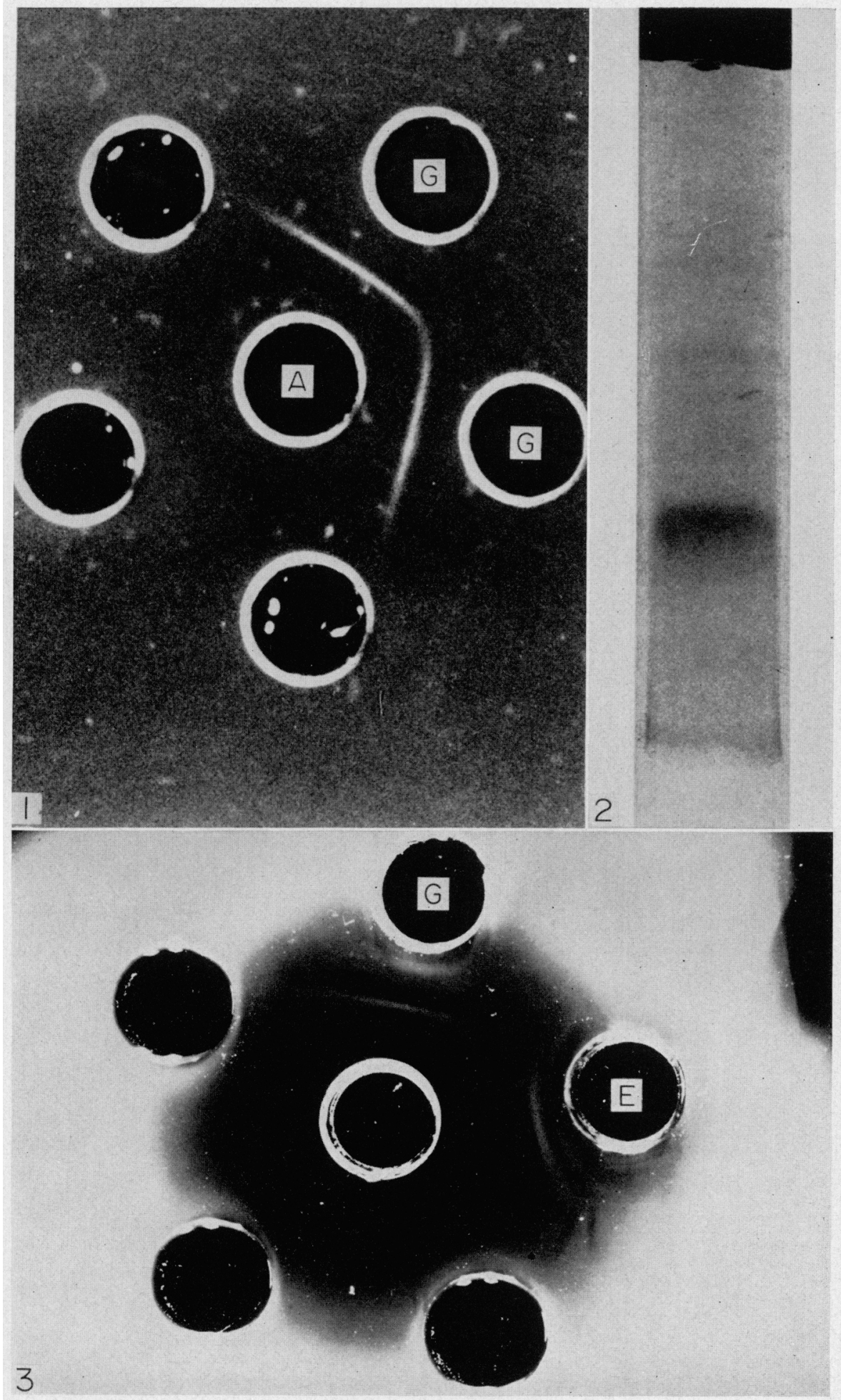


PIATE2

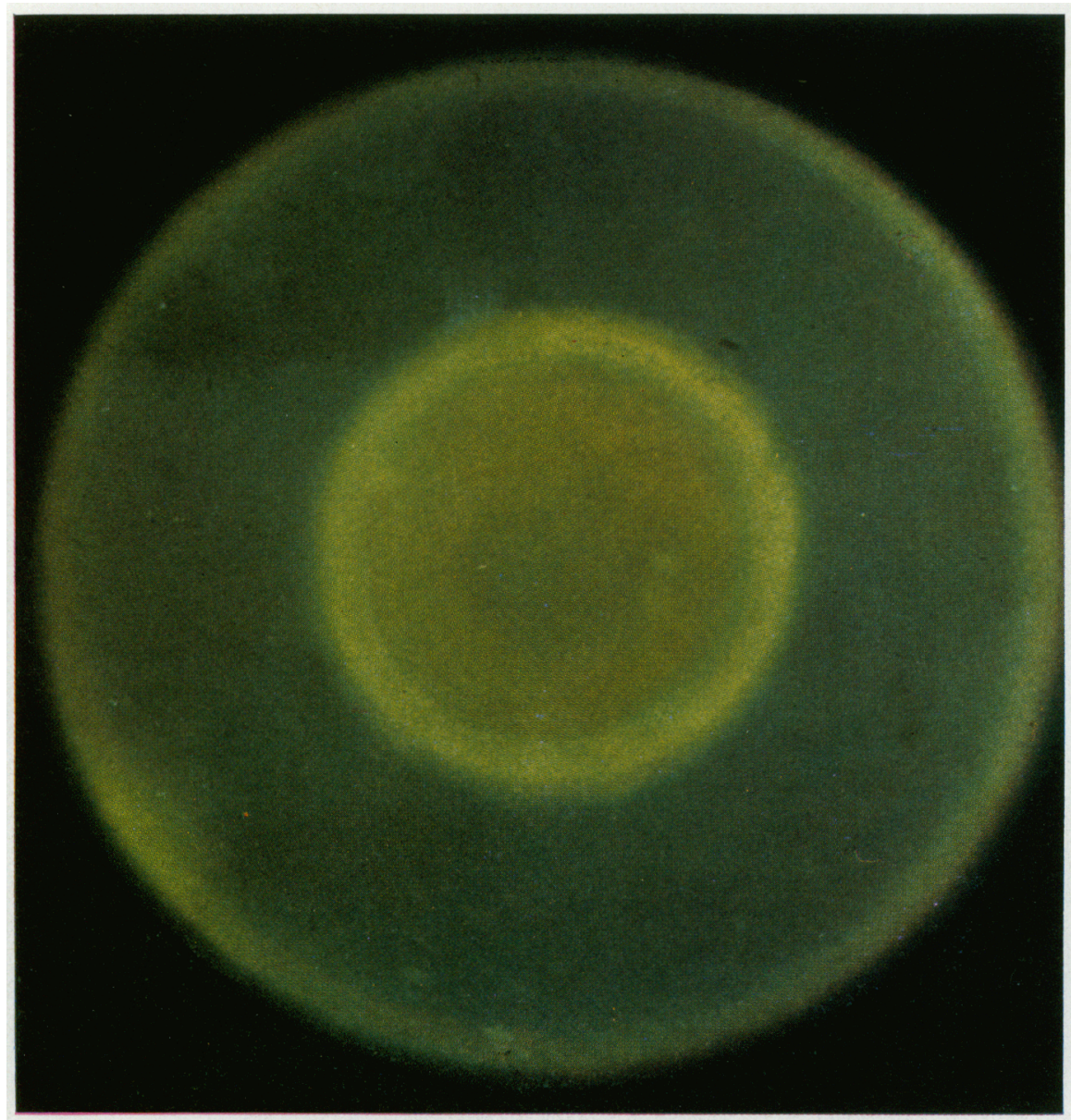

Fic. 4. Reaction of 3-day-old rabbit eggs with FI'le-labelled antiglycoprotein. The conditions for the reaction are elescribed under "Naterials and Methods". 


\section{Dissociation of acidic glycoprotein}

The glycoprotein was dissociated into smaller sub-units by incubation at $37^{\circ} \mathrm{C}$ for $2 \mathrm{hr}$ in the presence of $0.1 \%$ SLS and $0.1 \%$ mercaptoethanol. The dissociated glycoprotein $(50 \mu \mathrm{g})$ was subjected to disc gel electrophoresis with the standard alkaline gel and buffer containing $0.1 \%$ SLS and $0.1 \%$ mercaptoethanol (Davis, 1964). One major component was observed when the gels were stained with amido black or PAS, but minor protein components were also present (Pl. 1, Fig. 2).

The molecular weight of the dissociated sub-unit was calculated using the technique developed by Shapiro et al. (1967). The polydisperse glycoprotein showed predominately one major band after treatment with SLS. This band migrated as a sub-unit or monomer of 73,000 mol. wt (Text-fig. 4).

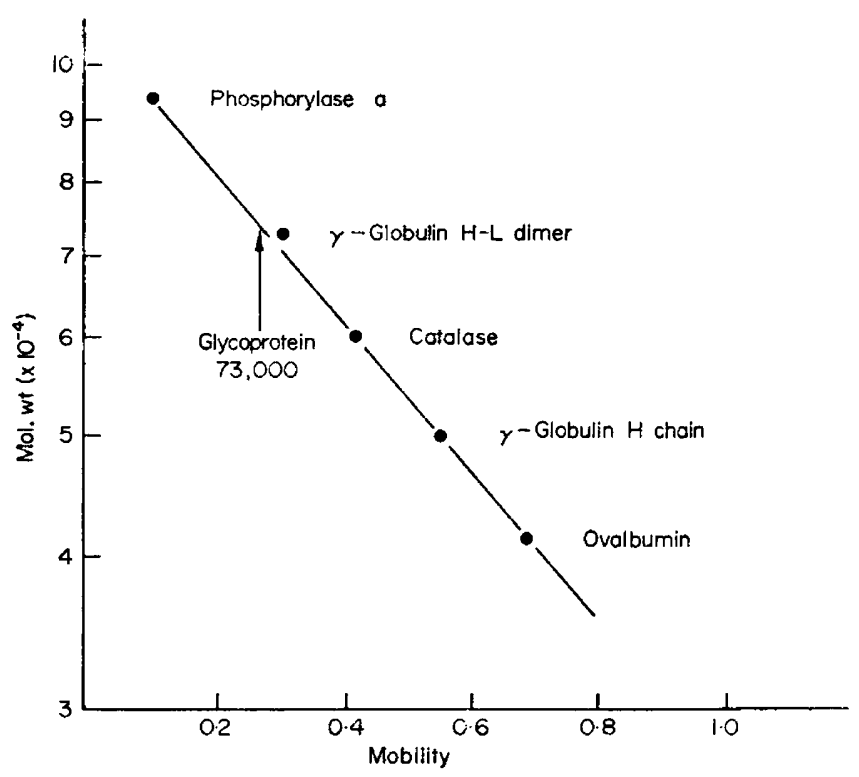

TEXT-FIG. 4. Molecular weight determination of dissociated glycoprotein. The conditions for electrophoresis are described under 'Materials and Methods'. The determined molecular weight was 73,000 daltons.

\section{Amino acid and carbohydrate analyses}

The isolated macromolecule contained almost equal (approximately $50 \mathrm{~mol} /$ $73,000 \mathrm{~g}$ of protein) amounts of aspartic acid, threonine, serine, glutamic acid and leucine (Table 1). The molecule was composed of approximately $30 \%$ by weight of carbohydrate, galactose being the most prominent sugar (Table 2). In addition to hexuronic acid, the glycoprotein also contained covalent sulphate (Table 2) indicating the presence of sulphated sugars. The identification of these sulphate esters has not been accomplished.

\section{Reaction of fluorescent antibody with 3-day-old eggs}

The FITC-antibody was incubated with 3-day-old eggs for $4 \mathrm{hr}$. Excess 
antibody was removed by washing with saline for $18 \mathrm{hr}$. A green fluorescence in ultraviolet light (PI. 2, Fig. 4) was seen after reaction of the egg with labelled antibody. The FITG-control (non-immunized) goat serum did not react with the 3-day-old eggs. Fluorescent antibody was also incubated with 4-day-old eggs that had lost most of their 'mucin' coat. When these eggs were examined microscopically with a u.v. light source, only a very low degree of fluorescence relative to the 3-day-old eggs was observed.

Table 1. Amino acid composition of glycoprotein in rabbit oviducal fluid

\begin{tabular}{|c|c|c|c|}
\hline Amino acid & $\begin{array}{c}\text { umol Amino } \\
\text { acid/0.190 mg } \\
\text { glycoprotein }\end{array}$ & $\begin{array}{l}\text { mol Amino } \\
\text { acid/73,000 } \mathrm{g} \\
\text { glycoprotein }\end{array}$ & $\begin{array}{c}\text { Nearest } \\
\text { integer } / 73,000 \mathrm{~g} \\
\text { glycoprotein }\end{array}$ \\
\hline $\begin{array}{l}\text { Aspartic acid } \\
\text { Threonine } \\
\text { Serine } \\
\text { Glutamic acid } \\
\text { Proline } \\
\text { Cysteine } \\
\text { Glycine } \\
\text { Alanine } \\
\text { Valine } \\
\text { Methionine } \\
\text { Isoleucine } \\
\text { Leucine } \\
\text { Tyrosine } \\
\text { Phenylalanine } \\
\text { Lysine } \\
\text { Histidine } \\
\text { Arginine }\end{array}$ & $\begin{array}{l}0 \cdot 1299 \\
0.1329 \\
0.1264 \\
0.1227 \\
0.0992 \\
0.0085 \\
0 \cdot 1057 \\
0.1100 \\
0.0920 \\
0.01437 \\
0.0568 \\
0.1366 \\
0.0364 \\
0.0704 \\
0.09123 \\
0.0426 \\
0.0658\end{array}$ & $\begin{array}{r}49 \cdot 96 \\
51 \cdot 11 \\
47 \cdot 92 \\
47 \cdot 19 \\
38 \cdot 15 \\
3 \cdot 26 \\
40 \cdot 65 \\
42 \cdot 31 \\
35 \cdot 38 \\
5 \cdot 53 \\
21 \cdot 84 \\
52 \cdot 54 \\
14 \cdot 00 \\
27 \cdot 08 \\
35 \cdot 09 \\
16 \cdot 38 \\
25 \cdot 31\end{array}$ & $\begin{array}{r}50 \\
51 \\
48 \\
47 \\
38 \\
3 \\
41 \\
42 \\
35 \\
6 \\
22 \\
53 \\
14 \\
27 \\
35 \\
16 \\
25\end{array}$ \\
\hline
\end{tabular}

Table 2. Carbohydrate composition of glycoprotein in rabbit oviducal fluid

\begin{tabular}{l|c|c|c}
\hline Carbohydrate & $\begin{array}{c}\text { umol Carbo- } \\
\text { hydrate } / 0 \cdot 190 \mathrm{mg} \\
\text { glycoprotein }\end{array}$ & $\begin{array}{c}\text { mol Carbo- } \\
\text { hydrate } 733,000 \mathrm{~g} \\
\text { glycoprotein }\end{array}$ & $\begin{array}{c}\text { Nearest } \\
\text { integer/73,000 } \mathrm{g} \\
\text { glycoprotein }\end{array}$ \\
\hline Sialic acid & 0.0494 & $19 \cdot 00$ & 19 \\
Galactose & 0.2245 & $86 \cdot 35$ & 86 \\
Uronic acid & 0.0696 & $26 \cdot 54$ & 27 \\
Glucosamine & 0.0893 & $34 \cdot 35$ & 34 \\
Galactosamine & 0.05691 & $21 \cdot 88$ & 22 \\
Fucose & 0.00810 & $3 \cdot 11$ & 3 \\
\hline $\mathrm{SO}_{4}=$ & 0.07588 & $29 \cdot 18$ & 29 \\
\hline
\end{tabular}

Reaction of lysed eggs with antibody

Forty-three 3-day-old rabbit eggs were lysed in $0.1 \mathrm{ml}$ of a $2 \%$ SLS and $2 \%$ mercaptoethanol solution. After dissolution, the SLS and mercaptoethanol were removed by exhaustive dialyses ( 4 days). The dialysate was concentrated and allowed to react against anti-glycoprotein (PI. 1, Fig. 3). After SLS dissociation and dialysis, both the coated egg and the purified glycoprotein 
antigens formed multiple precipitant bands when allowed to react against anti-glycoprotein.

\section{DISCUSSION}

We have isolated a large molecular weight acidic glycoprotein from rabbit oviducal fluid. The fractionation pattern indicates that the glycoprotein exists as a very high molecular weight polydisperse aggregate. Ultracentrifugation of the glycoprotein also indicated polydispersion. The purified material aggregated with ageing or freezing and thawing. The glycoprotein became immobile in electrophoresis and much less mobile in agarose gel.

The change in the physical properties of this glycoprotein was assumed to be the result of aggregation. However, we cannot explain why similarly prepared samples, which had not aged, varied in the degree of aggregation.

The large molecular weight of the glycoprotein, indicated by the fractionation pattern on Sepharose 4B, facilitated its purification from the rest of the proteins in the fluid. Except for DNA or RNA, the presence of such high molecular weight physiological polymers would not be expected in a biological fluid. Since no ribose, deoxyribose or phosphate was detected with standard methods in the isolated material, the presence of DNA and RNA can be excluded.

Fractionation of the oviducal fluid resulted in the isolation of an acidic glycoprotein which gave one major band which stained for both protein and carbohydrate when subjected to electrophoresis on cellulose acetate strips. Surprisingly, this sample gave a single precipitant band when allowed to react against antibody in agarose gel. Treatment of the acidic glycoprotein with SLS resulted in dissociation of the aggregate to one major sub-unit with a molecular weight of 73,000 daltons. The minor bands may be additional sub-units of the same high molecular oligomer or represent impurities. Further purification of the high molecular aggregate may help resolve this point.

Fluorescent antibody (raised in the goat) to this acidic glycoprotein fraction reacted with 3-day-old rabbit eggs giving a green fluorescence which indicated common antigenic determinants for both the glycoprotein and the egg coat. Furthermore, disrupted eggs gave a positive precipitant reaction with the antibody which suggested that the acidic glycoprotein is associated with the tertiary or 'mucin' coat of the egg.

\section{REFERENCES}

Albersheim, P., Nevins, D. J., English, P. D. \& KARR, A. (1967) A method for the analysis of sugars in plant cell-wall polysaccharides by gas liquid chromatography. Carbohyd. Res. 5, 340.

Antonopoulos, G. A. (1962) A modification for the determination of sulfate in mucopolysaccharides by the benzidine method. Acta chem. scand. 16, 1521 .

Bacsich, P. \& Hamilton, W. J. (1954) Some observations on vitally stained rabbit ova with special reference to their albuminous coat. F. Embryol. exp. Morph. 2, 81 .

Braden, A. W. H. (1952) Properties of the membranes of rat and rabbit eggs. Aust. F. sci. Res. 5, 460.

Glark, H. F. \& Shepard, G. G. (1963) A dialysis technique for preparing fluorescent antibody. Virology, 20, 642.

Davis, B. J. (1964) Disc electrophoresis. II. Method and application to human serum proteins. Ann. N.Y. Acad. Sci. 121, 404. 
Dische, Z. (1947) A new specific color reaction of hexuronic acids. F. biol. Chem. 167, 189.

Hamner, G. E. \& Fox, S. B. (1969) Biochemistry of oviductal secretions. In The Mammalian Oviduct, pp. 343-346. Eds. E. S. E. Hafez and R. J. Blandau. University of Ghicago Press, Chicago.

Hamner, G. E. \& Williams, W. L. (1965) Gomposition of rabbit oviduct secretions. Fert. Steril. 16, 170.

Lowry, O. G., Roseborough, N. J., Farr, A. L. \& Randale, R. J. (1951) Protein measurement with the Folin phenol reagent. F. biol. Chem. 193, 265.

Ouchterlony, O. (1953) Antigen-antibody reaction in gels. Acta path. microbiol. scand. 32, 231.

Shapiro, S. S., Jentsch, J. P. \& YARD, A. S. (1971) Protein composition of rabbit oviducal fluid. 7. Reprod. Fert. 24, 403.

Shapiro, A. L., ViÑula, E. \& MAIzel, J. V. (1967) Molecular weight estimation of polypeptide chains by electrophoresis in SDS-polyacrylamide gels. Biochem. biophys. Res, Commun. 28, 815.

SpIRo, R. G. (1966) Analysis of sugars found in glycoproteins. In Methods of Enzymology, Vol. VIII, pp. 13-14. Eds. E. F. Neufeld and V. Ginsburg. Academic Press, New York.

Wells, A. F., Miller, G. E. \& NADEL, M. K. (1966) Rapid fluorescein and protein assay method for fluorescent-antibody conjugates. Appl. Microbiol. 14, 271. 